\title{
Penerapan Media Permainan Ular Tangga Untuk Meningkatkan Hasil Belajar Peserta Didik Pada Mata Pelajaran IPS Melalui Penerapan Media Permainan Ular Tangga
}

(Studi pada SD Inpres Watujara Kecamatan Ende Timur Kabupaten Ende)

Fransiska Blandina Karhe ${ }^{1}$

${ }^{1}$ Guru Sekolah Dasar Inpres Watujara

zefanobadhe@gmail.com

\begin{abstract}
ABSTRAK:
Tujuan penelitian ini untuk meningkatkan hasil belajar IPS dengan menerapkan media permaian ular tangga pada peserta didik kelas IV SDI Watujara tahun ajaran 2019/2020 yang berjumlah 19 orang. Penelitian ini termasuk Penelitian Tindakan Kelas (PTK). Teknik pengumpulan data menggunakan teknik observasi, angket, tes, dokumentasi, dan catatan lapangan. Data yang terkumpul dianalisis secara deskriptif kualitatif dan deskriptif kuantitatif. Hasil penelitian menunjukkan bahwa media permainan ular tangga dapat meningkatkan hasil belajar peserta didik kelas IV SDI Watujara. Hal ini dapat dilihat dari persentase hasil belajar yang mengalami peningkatan dari persentase ketuntasan klasikal yaitu $54 \%$ pada siklus I menjadi $100 \%$ pada siklus II
\end{abstract}

Kata kunci: Media Permainan ular tangga, hasil belajar, IPS

\section{PENDAHULUAN}

Guru sebagai salah satu faktor penentu keberhasilan peserta didik harus memahami kurikulum secara komprehensif mulai dari konsep teori sampai dengan implementasinya di dalam kelas. Namun, dalam pelaksanaan di lapangan tidak jarang ditemukan masalahmasalah dan kegagalan dalam pembelajaran. Pembelajaran kurang berhasil ditandai hasil atau nilai yang diperoleh peserta didik tidak memuaskan. Hal ini tentu saja perlu menjadi perhatian utama bagi guru. Seorang guru yang profesional harus mampu memunculkan inovasi dalam pembelajaranguna memperbaiki kualitas output yang optimal.

Umumnya pembelajaran yang bersifat hafalan dan berbentuk ceramah akan mempengaruhi hasil dalam belajar. Hal ini dilihat dari hasil belajar peserta didik pada pembelajaran IPS yang kurang bagus sebagai akibat kurang variasi guru dalam menerapkan model, metode dan media dalam pembelajaran. Dimyati (dalam Wati, 2012:2). Pelajaran IPS sebagai salah satu mata pelajaran wajib di sekolah formal, dengan materi pelajaran yang cukup padat serta sering berganti materi karena mengikuti perkembangan kurikulum, juga menjadi beban yang cukup berat bagi peserta didik untuk dapat berprestasi secara maksimal.

Berdasarkan hasil pengamatan peneliti pada kelas IV di SD Inpres Watujara Kecamatan Ende Timur Kabupaten Ende ditemukan beberapa penyebab rendahnya hasil belajar peserta didik dapat dilihat dari kurangnya perhatian dan kepuasan peserta didik pada saat proses pembelajaran IPS berlangsung. Hal ini ditunjukkan dengan kurang senangnya peserta didik pada pelajaran, misalnya (1). mengganggu temannya ketika pelajaran sedang berlangsung, (2). kurang antusias mengikuti pelajaran, ramai sendiri, ketika guru sedang menerangkan pelajaran, (3). merasa puas dengan nilai kurang, (4). aktivitas rendah pada saat guru memberikan pertanyaan hanya sebagian yang mengangkat tangan. (5). Suasana kelas yang kurang menyenangkan.

Faktor penyebab hasil belajar peserta didik kelas IV SDI wWatujara rendah adalah sebagai berikut. Pertama, metode mengajar guru kurang melibatkan peserta didik. Guru masih mendominasi pembelajaran sehingga interaksi hanya berlangsung satu arah. Kondisi ini menyebabkan peserta didik cenderung pasif dan kurang inisiatif sehingga mereka lebih banyak menunggu sajian dari pada mencari dan menemukan sendiri pengetahuan dan keterampilan yang mereka butuhkan. Peserta didik tidak terbiasa belajar secara mandiri untuk menemukan, mengembangkan dan menyampaikann ide atau gagasan baik dalam berinteraksi dengan peserta didik lain maupun guru. Kedua, kurangnya strategi dalam 
pemanfaatan pembelajaran berdampak pada kurangnya konsentrasi dan perhatian peserta didik dalam pembelajaran. Ketiga, pembelajaran berpusat pada guru, dengan model pembelajaran ceramah untuk pembelajaran IPS, terutama di kelas IV. Keempat, guru kurang menggali potensi peserta didik. Kelima, kegiatan pembelajaran kurang merangsang peserta didik untuk belajar aktif, yang pada akhirnya berakibat hasil belajarnya tidak optimal karena peserta didik tidak mengikuti jalannya proses pembelajaran dengan baik.

Mencermati permasalahan tersebut diatas maka perlu ditemukan solusi yang cerdas, tepat, kreatif dan inovatif. Salah satu solusi yang ingin peneliti tawarkan untuk bisa meningkatkan hasil belajar peserta didik kelas IV SD Inpres Watujara Kecamatan Ende Timur Kabupaten Ende adalah menerapkan media permainan ular tangga dalam proses pembelajaran yang sesuai dengan kebutuhan peserta didik. Adapun yang dimaksudkan kebutuhan peserta didik adalah (1) kebutuhan akan media yang menarik dan tidak membosankan, (2) kebutuhan akan media yang variatif, dan (3) kebutuhan akan media yang sesuai dengan karakteristik peserta didik usia sekolah dasar.

Pemilihan media permainan ular tangga dalam pembelajaran IPS karena media permainan ular tangga merupakan permainan yang sangat dekat dengan kehidupan anakanak dan dimainkan oleh anak-anak dan di dalam permainan ular tangga tersebut terdapat nilai-nilai kompetitif, kooperatif, dan hiburan. Dikatakan kompetitif dikarenakan dalam permainan ini ada 6 kelompok saling mengadu ketangkasan untuk berusaha menjadi pemenang. Dikatakan kooperatif, semua anggota kelompok saling bekerjasama dalam permainan. Dikatakan hiburan, dikarenakan selama permainan berlangsung, suasana gembira menyelimuti jiwa peserta didik.

Hal tersebut didukung pendapat beberapa ahli yang menyatakan bahwa betapa pentingnya perrmainan bagi anak. Menurut Ljublinskaja (dalam Monks-A.M.P dkk, 2006:133) Permainan sebagai pencerminan realitas, sebagai bentuk awal memperoleh pengetahuan. Hal ini juga di perkuat Freeman (dalam Munandar, 1995:76) yang menyebutkan bahwa pada umumnya para pakar sepakat bermain merupakan suatu aktivitas yang membantu anak mencapai perkembangan yang utuh, baik fisik, intelektual, sosial, moral dan emosioal. Rofi'uddin (dalam Widyawati, 2013:8) menyatakan bahwa penggunaan bentuk-bentuk permainan dalam pembelajaran akan memberikan iklim yang menyenangkan bagi peserta didik, sehingga proses belajar peserta didik dilakukan tanpa adanya keterpaksaan, tetapi justru dengan rasa keharmonisan. Selain itu, dengan bermain peserta didik dapat belajar dengan santai. Dengan cara santai sel-sel otak peserta didik dapat berkembang yang akhirnya peserta didik dapat menyerap informasi dan memperoleh kesan yang mendalam terhadap materi pelajaran. Materi pelajaran dapat disimpan terus dalam ingatan jangka panjang.

Pembelajaran IPS dengan menerapkan media permainan ular tangga, selain banyak keunggulannya seperti yang sudah dijelaskan diatas, juga banyak manfaatnya, diantaranya sebagai berikut. Pertama, dapat menghilangkan kebosanan dalam belajar IPS, jika guru hanya mereduksi pada teks yang ada dalam buku paket IPS dengan harapan tidak salah melangkah, maka akan memungkinkan peserta didik tidak mau membaca buku paket di rumah, karena peserta didik beranggapan bahwa semua akan disampaikan juga oleh guru dalam pembelajaran. Akibatnya peserta didik menjadi bosan dan tidak bergairah. Sebaliknya jika dalam pembelajaran IPS dilibatkan permainan maka pembelajaran menjadi menantang dan menyenangkan. Kedua, hasil belajar peserta didik meningkat karena peserta didik menemukan sendiri materi yang diajarkan dan bukan sekedar pemberitahuan dari guru. Ketiga, meraih makna belajar IPS melalui pengalaman-pengalaman yang pernah peserta didik alami, sehingga peserta didik dapat berfikir kritis dan kreatif dalam melihat hubungan manusia dan manusia dalam rangka mewujudkan manusia yang berkualitas yang mampu membangun diri sendiri.

\section{METODE}

Pendekatan dan jenis penelitian yang digunakan adalah menggunakan pendekatan kualitatif. Adapun jenis penelitian kualitatif yang digunakan adalah penelitian tindakan kelas atau Classroom Action Research. Penelitian ini bertujuan untuk mendeskripsikan proses pembelajaran yang dapat memperbaiki permasalahan tersebut. Pelaksanaan PTK mengacu pada model siklus PTK oleh Kemmis dan Taggart. Setiap siklus terdiri dari atas. Satu, planning (perencanaan). Dua, act (pelaksanaan/Tindakan). Tiga, observation (pengamatan). reflecting (refleksi). Hasil refleksi kemudian digunakan untuk memperbaiki perencanaan (revise plan) berikutnya. Jenis penelitian ini dirancang dengan rancangan Penelitian 
Tindakan Kelas (PTK) dalam bentuk guru sebagai peneliti, maka peneliti bekerja sebagai guru kelas yang merencanakan tindakan, mempersiapkan tindakan, melaksanakan tindakan, dan melaporkan hasil penelitian.

Subjek dalam penelitian yang akan diteliti yaitu peserta didik kelas IV SD Inpres Watujara tahun ajaran 2019/2020 yang berjumlah 19 orang.

Sumber data yang digunakan dalam penelitian ini adalah siswa dan guru. Data yang diperlukan terdri dari.Pertama, penerapan media permainna ular tangga. Kedua, hasil belajar peserta didik. Teknik pengumpulan data dalam penelitian ini adalah dengan menggunakan teknik observasi, angket, tes, dokumentasi, dan catatan lapangan.

\section{HASIL DAN PEMBAHASAN}

Upaya untuk meningkatkan hasil belajar peserta didik kelas IV SD Inpres Watujara Kecamatan Ende Timur Kabupaten Ende pada pelajaran IPS dilakukan dengan menerapkan media permainan ular tangga. Penerapan media permainan ular tangga sudah berjalan dengan baik. Hal ini ditunjukkan dengan adanya peningkatan hasil belajar dari siklus I ke siklus II. Adapun perolehan hasil belajar peserta didik pada siklus dapat dilihat pada tabel berikut.

Tabel 1.1 Perolehan Nilai hasil Belajar Peserta Didik Siklus I

\begin{tabular}{lll}
\hline No & Keterangan & Perolehan \\
\hline $\mathbf{1}$ & Nilai Tertinggi & 87 \\
$\mathbf{2}$ & Nilai terendah & 47 \\
$\mathbf{3}$ & Nilai rata-rata kelas & 71 \\
$\mathbf{4}$ & Jumlah peserta didik yang tuntas belajar & 13 \\
$\mathbf{5}$ & Jumlah peserta didik yang belum tuntas belajar & 11 \\
$\mathbf{6}$ & Presentase ketuntasan belajar & 54 \\
\hline
\end{tabular}

Berdasarkan data nilai hasil belajar peserta didik diketahui bahwa nilai tertinggi 87, nilai terendah 47 , nilai rata-rata kelas 71 , jumlah peserta didik yang tuntas belajar 7 orang, jumah peserta didik yang belum tuntas 12 orang dan presentase ketuntasan 54\%. Berdasarkan hasi analisis data siklus I belum mencapai kriteria ketuntasan minimal (KKM) sehingga dilanjutkan pada siklus ke-II.

Pencapaian hasil belajar yang belum maksimal pada siklus I disebabkan beberapa kendala, antara lain karena peserta didik belum terbiasa dengan pembelajaran menggunakan media permainan ular tangga.

Permainan ular tangga ini bukan hal baru bagi peserta didik, namun merupakan media yang baru diperkenalkan kepada siswa kelas IV SD Inpres Watujara Kecamatan Ende Timur Kabupaten Ende dalam proses belajar IPS. Aturan permainan Ular tangga yang diterapkan dalam pembelajaran IPS tentu merupakan hal yang berbeda dengan aturan permainan ular tangga yang diketahui peserta didik. Adanya anggapan bahwa proses pembelajaran dengan permainan merupakan kegiatan yang menyenangkan membuat peserta didik kurang memperhatikan aturan utama permainan dimana peserta didik harus menjawab sejumlah soal yang telah disiapkan. Karena perbedaan persepsi tersebut, banyak peserta didik yang melakukan permainan ular tangga tidak sesuai dengan aturan yang telah dibuat peneliti. Peneliti sedikit kesulitan dalam mengatasi kendala tersebut, dikarenakan anak usia sekolah dasar masih mempunyai ketertarikan yang besar dengan permainan sesuai dengan

Pencapaian hasil belajar yang belum maksimal pada siklus I juga disebabkan kontrol kelas guru yang kurang baik. Hal ini dikarenakan, kegiatan pembelajaran yang dilakukan pada siklus I merupakan kondisi pembelajaran yang baru pertama kali dilaksanakan dan guru belum menghafal dan terbiasa dengan karakteristik siswa-siswi kelas V SD Inpres Watujara Kecamatan Ende Timur Kabupaten Ende. Untuk mengatasi tersebut, guru menggunakan papan nama untuk lebih mengenal peserta didik pada siklus II. Selain itu, guru menyiapkan reward pada siklus II untuk lebih membangkitkan motivasi siswa agar berusaha meningkatkan hasil belajar. berikut.

Adapun perolehan hasil belajar peserta didik pada siklus dapat dilihat pada tabel

Tabel 1.2 Perolehan Nilai Hasil Belajar Peserta Didik Siklus II 


\begin{tabular}{lll}
\hline No & Keterangan & Perolehan \\
\hline $\mathbf{1}$ & Nilai Tertinggi & 100 \\
$\mathbf{2}$ & Nilai terendah & 80 \\
$\mathbf{3}$ & Nilai rata-rata kelas & 92 \\
$\mathbf{4}$ & Jumlah peserta didik yang tuntas belajar & 24 \\
$\mathbf{5}$ & Jumlah peserta didik yang belum tuntas belajar & - \\
$\mathbf{6}$ & Presentase ketuntasan belajar & 100 \\
\hline
\end{tabular}

Berdasarkan data nilai hasil belajar peserta didik dapat diketahui bahwa nilai tertinggi 100, nilai terendah 80 , nilai rata-rata kelas 90 , jumlah peserta didik yang tuntas belajar 19 orang dan presentase ketuntasan 100\%. Berdasarkan hasi analisis data siklus II sudah meningkat, dengan demikian proses penelitian tidak dilanjutkan pada siklus berikut.

Pada siklus II hasil belajar meningkat sangat siginifikan, dimana seluruh siswa telah tuntas mencapai kriteria ketuntasan yang ditentukan. Kondisi pembelajaran di siklus II sangat berbeda dengan siklus I. Perlahan peserta didik mulai memahami aturan permainan ular tangga ketika diarahkan oleh guru. Peserta didik juga terlihat semangat karena guru menyiapkan reward untuk membangkitkan semangat belajar Peserta didik. Motivasi merupakan dorongan untuk melakukan sesuatu (Sardiman, 2011:73). Dengan menyiapkan reward, memberikan dorongan bagi peserta didik untuk lebih meningkatkan hasil belajar.Dengan melibatkan permainan dalam pembelajaran IPS maka pembelajaran menjadi menantang dan menyenangkan. Hasil belajar peserta didik meningkat karena peserta didik menemukan sendiri materi yang diajarkan dan bukan sekedar pemberitahuan dari guru. Selain itu, peserta didik dapat meraih makna belajar IPS melalui pengalaman-pengalaman yang pernah peserta didik alami,sehingga peserta didik dapat berfikir kritis dan kreatif dalam melihat hubungan manusia dan manusia dalam rangka mewujudkan manusia yang berkualitas yang mampu membangun diri sendiri.

\section{PENUTUP}

\section{Kesimpulan}

Berdasarkan hasil penelitian dan pembahasan, maka dapat ditarik tiga kesimpulan meliputi. Pertama, penerapan media permainan ular tangga dapat meningkatkan minat belajar peserta didik kelas IV SD Inpres Ende. Penerapan media permainan ular tangga dapat meningkatkan hasil belajar peserta didik kelas IV SD Inpres Watujara Kecamatan Ende Timur Kabupaten Ende meningkat 46\% dari siklus I sebesar 54\% ke siklus II menjadi $100 \%$. Ketiga, penerapan media permainan ular tangga yang dilakukan terdiri dari langkah-langkah. (1). Peserta didik membentuk kelompok, tiap kelompok terdiri dari 4 peserta didik, (2). Guru membagikan satu set permainan ular tangga dan lembar daftar pertanyaan berupa kartu soal yang berkaitan dengan materi pemblajaran untuk dijawab peserta didik, (3). Setiap pemain memilih sebuah alat penghitung yang berbeda warna, (4). Peserta didik melakukan undian untuk menentukan urutan bergilir melempar dadu dan menjawab pertanyaan yang tersedia, (5). Permainan dimulai dari start, pemain pertama melempar dadu dan menjawab soal tentang materi pelajaran nomor 1. Apabila jawaban benar maka peserta didik tersebut boleh melanjutkan perjalanan ke angka berikutnya, dan apabila jawaban salah maka peserta didik tersebut harus berhenti di kotak start, (6). Pemain kedua berganti sebagai pelempar dadu dan menjawab pertanyaan nomor 2 , begitu juga seterusnya secara bergiliran. Pada giliran pemain menggelindingkan dadu, apabila mata dadu menunjukkan angka 6 maka pemain tersebut dapat melempar dadu lagi, (7) Jika pin berhenti di kaki sebuah tangga, maka pemain tersebut boleh naik ke bagian atas tangga. Jika pin pemain berhenti di ekor ular, maka pemain tersebut harus turun sampai akhir dari ekor ular tersebut. Lebih dari satu alat penghitung bisa menempati kotak yang sama sampai permainan mulai kembali/bergerak. (8) Kelompok yang cepat menyelesaikan kartu soal dengan permainan ular tangga, maka kelompok tersebutlah yang pemenang. hal ini terlihat dari presentase peningkatan keterlaksanaan pembelajaran dengan penerapan media permainan ular tangga dari siklus I, ketercapaian pelaksanaan penerapan media permainan ular tangga adalah $71 \%$. Setelah beberapa perbaikan dalam pelaksanaan, maka pada siklus II pelaksanaan media tersebut mengalami peningkatan mencapai $95 \%$. 


\section{Saran}

Berdasarkan kesimpulan di atas, maka dikemukakan empat saran sebagai berikut . Pertama, penerapan media permainan ular tangga dapat meningkatkan hasil belajar dan minat belajar IPS, sehingga diharapkan guru hendaknya dapat memilih model, media pembelajaran yang tepat dan disesuaikan dengan karakteristik peserta didik agar tujuan pembelajaran tercapai. pemilihan media pembelajaran hendaknya disesuaikan dengan kesiapan belajar peserta didik dan jenis materi yang diberikan Penggunaan media dalam kelompok dan mengandung unsur permainan akan membuat pembelajaran lebih bermakna bagi peserta didik. Kedua, sebaiknya sebelum guru menerapkan media permainan ular tangga dalam pembelajaran hendaknya memberikan instruksi yang jelas kepada peserta didik mengenai apa yang harus dilakukan pada setiap tahapan belajar sambil bermain menggunakan media permainan ular tangga, memperhatikan pengelolahan kelas dan manajemen waktu yang tepat. Selain itu, sebaiknya dalam pengamatan aktivitas permainan ular tangga menggunakan lebih dari satu observer agar pengamatan aktivitas permainan ular tangga selama pembelajaran berlangsung lebih teliti. Ketiga, Dalam upaya peningkatan mutu pendidikan di Sekolah Dasar diharapkan sekolah dapat mengadakan pembinaan dan pelatihan berkelanjutan terhadap guru-guru SD Inpres Watujara Kecamatan Ende Timur Kabupaten Ende untuk meningkatkan pengetahuan dan keterampilan dalam menerapkan berbagai media pembelajaran pada umumnya dan media permainan ular tangga pada khususnya untuk meningkatkan kualitas pembelajaran. Keempat, penggunaan media permainan ular tangga dalam pembelajaran IPS hendaknya perlu dikembangkan untuk memperbaiki kekurangan agar memperoleh hasil yang lebih baik lagi. Peneliti lain diharapkan dapat melakukan penelitian lanjutan dengan menggabungkan atau mengkolaborasikan dua model pembelajaran yang berbeda dengan media pembelajaran yang sesuai, dan materi pada siklus I dan siklus II hendaknya materinya berkelanjutan, sehingga pencapaian nilai bukan karena pengulangan materi melainkan karena media permainan ular tangga yang diterapkan.

\section{DAFTAR RUJUKAN}

Koerudin, Ending., Permana Pepeng dan Susilawati Susi. 2013. Teknik Permainan Ular Tangga (Schlangen und Leitern) dalam Pembelajaran Kosakata Bahasa Jerman. Jurnal (http//www. Scholar.google.co.id) diakses 09 Mei 2014.

Munandar, Utami. S.C. 1995. Bimbingan dan Koseling Anak Berbakat. Surabaya: Makalah dalam Kongres VIII dan Konvensi Nasional X IPBI.

Mutiah, Dina. 2012. Psikologi Bermain Anak Usia Dini. Jakarta: Kencana Prenada Media Group.

Monks, dkk. 1994. Psikologi Perkembangan. Yogyakarta: University Press NY:Holt, Rinehart and Winston, Inc.

Schunk. H. Dale, Pintrich. R. Paul \& Meece. L. Judith. 2012. Motivasi dalam Pendidikan. Jakarta: PT Indeks.

Trianto. 2009. Mendesain Model Pembelajaran Inovatif Progresif Jakarta: Kencana Prenada Group

Wati, Septiana E. 2012. Peningkatan Hasil Belajar IPS melalui Model Pembelajaran Ular Tangga di Kelas IV SDN Balowerti 3 Kota Kediri. Skripsi tidak diterbitkan. Malang: Universitas Negeri Malang.

Widyawati. 2013. Peningkatan kemampuan sosial emosional melalui permainan gobak sodor pada anak kelompok B TK PGRI 02 Wagir Malang. Skripsi tidak diterbitkan. Malang: Universitas Negeri Malang. 